MANUAL ON CONVERSION TO LC BOOK CLASSIFICATION

A grant of $\$ 2,000$ to Desmond Taylor, director, and Raimund Matthis, technical services librarian, of the University of Puget Sound's Collins memorial library, for preparation of a manual on the Library of Congress' classification of books has been made by the Council on Library Resources.

The manual will be based in part on the practical experience gained in converting from the Dewey Decimal System to the Library of Congress' classification system at the Tacoma, Washington, university library. The authors expect to cooperate with the processing department at the Library of Congress in the project.

The philosophy and rationale for favoring the Library of Congress' system, detailed procedures for conversion to the system, conversion cost data, and other information will be included in the manual.

\section{SCIENTIFIC AND TECHNICAL INFORMATION}

The Bibliographic Systems Center of the school of library science, Western Reserve University, announces that with the aid of a Unesco grant it will establish a Clearinghouse for Scientific and Technical Classification Schedules, Key-word and Descriptor lists and Thesauri in the English language. The provision of this type of material, for the purpose of assisting individuals and organizations in their scientific and technical information retrieval problems, is the Center's main function. Upon inquiry, the Center informs the user of items relevant to his areas of interest; the user may then borrow any of the material for a fourweek loan period.

As a consequence of the Unesco grant, the Center will be able to enlarge substantially the basic collection (approximately nine hundred titles in the scientific and technical fields) and will be able to continue free service to users. Please address inquiries to: Bibliographic Systems Center, School of Library Science, Western Reserve University, 11161 East Boulevard, Cleveland, Ohio 44106.

\section{LC PRESERVATION PROGRAM}

Frazer G. Poole has been appointed Preservation Officer at the Library of Congress. In his new duties, Mr. Poole will direct the Library of Congress program for the physical preservation of its varied types of library materials, developing managerial and technical solutions not only for the library's use but also for use or adaptation by other libraries faced with similar preservation problems. Libraries throughout the U.S. are concerned about preserving their collections from the inroads of time and the effects of environment. They not only face problems with paper, ink, and bindings of traditional materials such as books, manuscripts, and newspapers, but also deal with unknown factors affecting twentieth century forms, such as films and magnetic tapes. Together with the Association of Research Libraries Preservation Committee, the Library of Congress has developed a national preservation program. This includes a campaign to rescue thousands of "brittle books" printed on acid paper in the last one hundred years and now disintegrating in libraries all over the country. Through a recent grant from the Council on Library Resources, Mr. Poole also will direct a pilot project on this problem.

\section{ACLS COMMITTEE FOR RESEARCH LIBRARIES}

The American Council of Learned Societies has announced the appointment of a committee of scholars, librarians, and university presidents to propose programs of action to meet the urgent and long-term needs of American research libraries.

Research libraries tend to double in volumes held every fifteen years and the result is increasingly critical shortages. One important topic the committee will take up is the extent to which shortages of space, personnel, and funds can be overcome by the application of modern technology.

The study is being made at the request of the National Advisory Commission on Libraries. It is being financed through a grant of $\$ 39,300$ from the Council on Library Resources.

Members of the ACLS committee are: William O. Baker, Bell Telephone Laboratories; Kingman Brewster, Yale University; Douglas Bryant, university librarian, Harvard University; T. Robert S. Broughton, University of North Carolina; Lyman S. Butterfield, Massachusetts Historical Society; William S. Dix, librarian of Princeton University; Warren Haas, director of libraries, University of Pennsylvania; Chauncy Harris, University of Chicago; James D. Hart, University of California, Berkeley; H. Field Haviland, Jr., Brookings Institution; Gordon N. Ray, John Simon Guggenheim Memorial Foundation; Robert G. Vosper, university librarian, University of California, Los Angeles; Herman B Wells, Indiana University; Walter Muir Whitehill, director and librarian, Boston Athenaeum; Gordon R. Williams, director, Center for Research Libraries, Chicago; Edwin Wolf 2nd, librarian, Library Company of Philadelphia; and Louis B. Wright, director, Folger Shakespeare library. 